\title{
A Parks System for West Malaysia
}

\author{
Bruce E. Weber
}

West Malaysia has elephants, tapir, seladang, tiger and the Sumatran minoceros among its fauna, and a wealth of flowering plants - some 8000. The author spent a year attached to the Federal Game Department, with the task of surveying all likely areas for national parks in order to preserve a representative selection of this remarkable wildlife. His report to the Game Department, of which this is a summary, proposed seven major reserves - one national park (already in existence) and six national monuments.

West Malaysia - the modern name for Malaya - has progressed faster and farther in this last decade than in the whole previous century. But, as development proceeds uncontrolled, natural areas diminish. Seacoasts, rivers and wildlands are increasingly threatened, and remnant blocks of forest near the growing towns are converted to agriculture, settlement, commercial forests and other uses. This is not to argue against progress and development, but national parks ought to be an essential part of this development. Malaya's wildlife heritage includes wild buffalo, Sumatran rhinoceros, elephant and tiger. The loss of these and others would not only be a loss to future generations of Malaysians, but to all mankind. The national park system proposed here would set aside those few special areas of natural splendour that are left.

\section{Seven Areas}

Most of Malaya's 50,910 square miles is mountainous, clothed by dense tropical rain forest, with a coastal alluvial plain. The mountains scarcely exceed $7000 \mathrm{ft}$, and are far too low to record the effects of climatic tree lines, snows or glaciation. A national park system for Malaya needs to include two types of area: national parks and national nature monuments. The first is defined as spacious land and water areas of nationwide interest and unexcelled quality, established as inviolable sanctuaries for the permanent preservation of scenery, wilderness, and native flora and fauna in their natural condition; the latter is used here for similar but smaller areas that do not possess such a wide variety of outstanding features. There are seven areas that should form the core of Malaya's national park system, but only one, the Taman Negara, appears to have all the qualifications of a great national park; all other sites qualify as national nature monuments. However, the essential idea behind both is to protect and preserve natural phenomena while allowing limited public access.

\section{Taman Negara}

Presently Malaya's only real national park, the Taman Negara is administered by the Federal Game Department and not a state government. One of the finest floral and faunal reserves in Asia, it 
comprises 1677 square miles of undisturbed tropical forest, ranging from lowlands at $400 \mathrm{ft}$ to the highest hills in the country, culminating in Gunong Tahan at $7186 \mathrm{ft}$. The many types of vegetation range from lowland humid tropical forest to montane oak and ericaceous forests at the higher elevations. In the rain forest the tall evergreen trees attain heights of between 100-150 feet, and it is rich in woody and herbaceous epiphytes as well as thick-stemmed lianes. It is also rich in woody tree species: Malaya, with a flora of about 8000 flowering plants, is estimated to have at least 2000 trees, a large proportion of which occur in the lowland forest.

\section{Flora}

In the high forests the trees are generally lower and more scattered, the canopy consisting mostly of oaks, Fagaceae, with some conifers, Dacrydium, Podocarpus, and Agathis sp., and the shrub layer of many rattans and dwarf palms, Arenga and Licuala sp. The abundance of epiphytic orchids, mosses, and ferns decreases with increasing altitude until in the cloud forest at $6000 \mathrm{ft}$, where there is low-level cloud at least part of each day, the trees are typically short and gnarled.

The large area and the variety of habitats account for the great diversity of wildlife in the Taman Negara. Several herds of seladang Bos gaurus, also known as gaur or wild buffalo, range along the major river systems. A few Sumatran rhinoceros Didermocerus sumatrensis, extremely rare throughout southeast Asia, inhabit the rugged terrain in the high hills but are infrequently encountered. Elephants Elephas maximus and tapir Tapirus indicus are in the lowland forest along with wild pigs Sus scrofa, sambar deer Cervus unicolor, and many felines, including tiger Panthera tigris. Rodents, squirrels, monkeys, barking deer Muntiacus muntiak and mouse deer Tragulus sp are abundant.

Although the Taman Negara exists primarily as a strict nature reserve, public access is considered important, and there are facilities for visitors. Park headquarters, at Kuala Tahan on the Tembeling River is 35 miles north of the nearest town of Kuala Tembeling, and river boats connect the two. A first-class rest house, four chalets and recently, a youth hostel have been built, and two fishing lodges and two halting bungalows enable people to visit less accessible forest. Short trails lead to salt licks and tree hides where animals can be watched.

The park originated with state legislation in 1925, but there has been some, very restricted, development in the last three decades, largely due to financial need, but also to the intervention of the Japanese war (1941-1945) and the Communist emergency (1948-1960) which made the forest very unsafe. Since then interest in the park has increased. Two major problems, however, are the park's inaccessibility and the lack of communications inside it. To make the park headquarters more accessible requires the building of a government road to the nearest town. Attempts to enlarge the size of the boats, as well as to encourage the public to utilise the park airstrip, have unfortunately failed because both methods proved more costly than the present system of river boats. A road across the park, linking headquarters with the railway on the western boundary, would improve communications within the park and make interesting features more accessible. 
1. Taman Negara

2. Tasek Bera

3. Mersing Coast

4. Limestone Hills

5. Templer Park

6. Batu Caves

7. Kuala Selangor

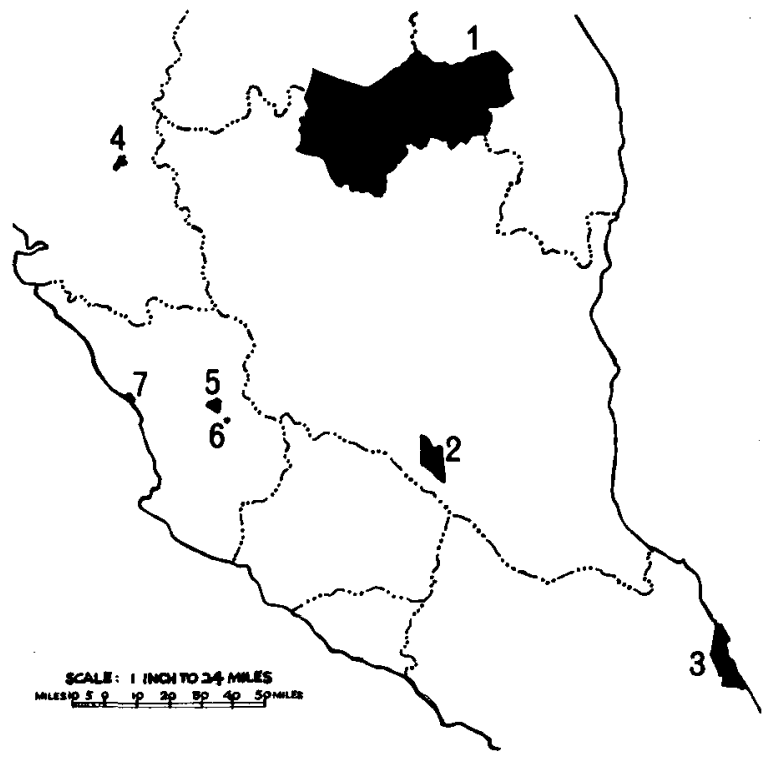

\section{Tasek Bera}

'The swamp of changing colours', Tasek Bera, in Pahang state is the only major inland water in the peninsula, the habitat of many significant plant and animal species. A national monument is proposed that would include an area of 63 square miles, mostly wetland. The Tasek itself consists of a series of marshes separated by many small swamps, and connected by narrow, fast-flowing streams. It varies between half and three miles in width and is approximately 17 miles long, creating a wet area of about 40 square miles.

The wildlife includes elephants, tigers, tapirs, as well as numerous smaller animals. The water itself, brown and acidic, harbours the gharial crocodile Tomistoma schlegeli and many amphibians. Reedbeds, forests and grassland support an abundance of bird species. Lord Medway, formerly of the University of Malaya, compiled a list of 215 forms that probably occur - more than half of West Malaysia's 575 species.

The fish fauna includes many rare and unique forms. Dr Jose Furtado, of the University of Malaya, has recorded over 144 different species, from the very small to game fish sometimes weighing more than $20 \mathrm{lbs}$. Some fish have become extremely rare in Malaya and others are extinct in their former ranges in Asia: Scleropages formosus is practically a living fossil and Tasek Bera is one of the only locations where it now exists. Intensive studies of the aquatic community are being performed over the next few years by Japanese and Malaysian scientists as part of the world-wide International Biological Programme.

The flora comprises at least three types - swamp, forest and grassland. The swamp vegetation consists predominantly of rasau Pandanus sp., mixed with various reeds and submerged plants like 
bladderwort Utricularia sp. Rasau typically occupies the deep channels, and its stems often grow up from the bottom through twelve feet of water. Forests occur on islands of deep peat and are usually low, barely exceeding 80 feet, with gnarled trees, their branches covered by epiphytic bryophytes, ferns and orchids.

Unfortunately, this superlative area is being increasingly disturbed by timber extraction, iron mining, and settlement. It is very necessary that a reserve be created here, both to protect the habitats and to provide for animals driven out of the surrounding forests by the conversion to agricultural and plantation-forestry use. Destruction of aquatic environments is depleting the aquatic fauna, mostly through excessive silting of rivers as a result of mining. One large inland pollution-free water reserve is essential if this fauna is to be saved from extinction. Creating a Tasek Bera National Monument would be a step towards this.

Tasek Bera is similar in many respects to the Everglades in Florida and, as has been done there, long elevated walkways could be constructed over the reedbeds and through the wet jungle to enable the public to see the swamp's wildlife, but keeping it as natural as possible and allowing only development that is strictly necessary. It has great potential and a ride in a small dugout through the densely vegetated channels of the swamp offers unusual plants and attractive birds, and the calls of insects, birds and mammals.

\section{Mersing Coast}

This expanse of 76 square miles of forest and shore on the south-east coast, in Johore, deserves prime consideration for designation as a national monument. Approximately 20 miles in length and between three and five miles wide, only a small part has been disturbed by logging or shifting cultivation. The 22 miles of coastline bordering the South China Sea gives excellent potential for seaside recreation as well as nature preservation.

The coast is subject to the wave action of seasonal monsoons that correspondingly affect the shore topography and the distribution of plant species. The sandy beaches are flanked by a narrow band of ru trees Casuarina equisetifolia, whose seed is dependent upon the seasonal high tides to distribute it far enough inland for survival. Other species, such as Terminalia catappa, Callophyllum inophyllum, and various screw-pines, Pandanus sp., are found in association with the casuarina. Further inland is the spiny nebong palm Oncosperma horrida. Wave action often closes off the estuaries of streams draining the interior so that silting occurs and the resulting mudflats serve as a substrate for mangroves. There are small areas of coastal meadow within the beach environment, no doubt extended by the practice of periodically burning the vegetation in order to attract animals for hunting.

The alluvial fresh water swamp forest along this coast has interested botanists and foresters for decades because it demonstrates a strong Bornean floristic distribution not found elsewhere on the Malay Peninsula. The region is an ideal field laboratory, and studies of the distribution patterns of some species here will ultimately yield answers to questions of basic economic importance - such as, why West 
Malaysia has so many species from Borneo or East Malaysia but lacks those swamp species of greatest commercial value.

Lowland dipterocarp forest covers the hills, the highest of which just barely top 500 feet. Tree trunks and branches are festooned with epiphytic ferns, mosses and orchids, while the ground layer of the forest consists of large areas of bertam palm Eugeisonna tristis as well as various rattans. A strange palm, Teysmania sp., occurs on the well drained slopes. This has interested botanists because it is considered an important evolutionary link between the fan palm and pinnate palm groups.

Mammals include representatives of the major Malayan species, plus some rarities - elephants, tapirs, and many felines, as well as several species of gibbons Hylobates sp, and monkeys, Presbytis and Macaca sp. They appear to mingle in all the different vegetative zones and it is probably not unusual for an individual animal to utilise most of the environments in a single day. The rare Sumatran rhinoceros is certainly there. One individual that was tracked seemed to utilise the beach, the alluvial swamp, and the dipterocarp forest within a period of several hours as part of a regular routine.

Development should be minimal, but two essential projects for public access are a road to connect the Singapore-Mersing highway with the southern boundary of the national monument, and a good system of trails to allow rangers to guard effectively against poaching and the theft of jungle produce - both serious problems at the present time.

\section{Limestone Hills}

A national monument to embrace the steep-faced limestone cliffs bordering the Kinta Valley in central Perak, some rising precipitously to over 1800 feet, is proposed, about nine square miles in extent. These ancient hills are a conspicuous feature of the scenery in northern Malaya, remnants of a previously large limestone expanse that covered the entire Malay-Thai Peninsula 300 million years ago.

The biology of the limestone hills has fascinated scientists for decades. Strongly drained, they stand as islands of calcareous or magnesian rocks in a sea of generally acidic soils. The isolation of this unique habitat in Malaya has given rise to a relict flora and fauna that is rich in endemics and locally evolved variants. There is a wide range of ecological niches, due to variation in the rock composition, the degree of drainage, and exposure, which largely accounts for the great number of species on the massifs. Both on the dry cliff faces and in damp hollows of the hanging valleys, there are rare species to be found that exist nowhere else in Malaysia. Scientists continue to study the area and economic botanists especially recognise its importance as a source of genetic material for plant breeding (Allen 1961).

Many plant species are rock-loving and exist only on these calcareous soils. Henderson, of the Singapore Botanical Gardens, listed about 200 species of flowering plants in Malaysia that are known to exist only in limestone habitats and 65 per cent of these are endemic (Henderson 1939). Although botanists have been collecting plants from the limestone rocks for more than 70 years, many of the plants are so rare that they have only been refound once or twice. Some may even have 
disappeared. The Ipoh chirita $C$. sericea, belonging to the gloxinia family, with large lilac flowers, is becoming rare. Other species completely new to science are still being discovered (Allen 1961).

The fauna is just as interesting. Serow Capricornis sumatraensis, leopard Panthera pardus, and the dusky leaf monkey Presbytis obscurus are visitors to the hills. The cliff swallow Hirundo daurica, Madoc's blue thrush Monticola solitaria, and the blue whistling thrush Myiophoneus flavirostris nest in caves or holes on the cliff faces.

Unfortunately both flora and fauna are extremely sensitive to outside interference, and are now threatened by commercial exploitation. For at least half a century tin mining, and to a lesser extent other types of mining, has been carried out at the base and on the lower slopes of some of the hills with surprisingly little damage to their appearance. The gradual introduction of quarries was more damaging, but only to limited areas. Now there is not one of the larger outcrops in the Kinta Valley that is not covered in part, or completely, by prospecting licences or by working mines. Furthermore, illegal occupants often cultivate any of the accessible slopes.

At least one reserve is needed in the Kinta Valley to protect the unique biology of the region from being burned and mined into extinction. The proposed location of the national monument includes 2000 acres of the Gunong Tempureng/Gunong Gajah limestone massif, 20 miles south of the town of Ipoh, along the Federal Highway. One of the highest limestome hills in Malaya (2005 ft), it has the added advantage of possessing caves and odd-shaped rock formations, and it adjoins the granite foothills of the main range which will guarantee safe access for many animals to the forest.

The location of the suggested Limestone Hills National Monument is almost ideal: within an hour's drive of Malaya's third largest town and directly on the main north-south road connecting the two larger population areas, Penang and Kuala Lumpur. Access into the immediate area is excellent because of the fine network of roads contructed over the past two decades by tin mining companies.

The Kinta Valley covers more than 300 square miles. Surely it could yield four or five square miles in order to preserve for future generations a locality of magnificent scenery and unique biology that is of educational and scientific value to the entire nation.

\section{Templer Park}

Established as a pseudo 'national park' in 1955, Templer Park covers 4000 acres on the main road north of Kuala Lumpur, within an hour's drive of the capital. It is a gazetted game reserve, consisting of open country formerly settled and mined for tin, together with a large area of forest. A number of streams flow through the park and there are also some large ponds resulting from past tin mining. Bukit Takun, a large and beautiful limestone tower, with sheer walls towering more than 1500 feet above the valley floor, is a major topographical feature.

Templer Park is a fine example of the humid tropical forest, and deserves to be designated a true part of the national park system as well as being an integral part of the development of Kuala Lumpur. 
Extensive forest reserves on three sides support a fauna including gibbons, monkeys, deer, and wild pig, and rarer species, including tapir, leopard and serow, have occasionally been encountered (Dunn 1965). Floristically the areas disturbed by past tin-mining provide as much interest as those of original forest. A variety of terrestrial wild orchids - Arundina, Graminaefolia, Bromheadia and Spathoglottis sp. - live on the infertile tin-tailings, and wherever past mining exposed a hard laterite pan (Mitchell 1959). A quartz ridge in one forest reserve is the site of an exceptional stand of tall conifer-like kapur trees Dryobalanops aromatica, the only large stand of this species known in western Malaya. Granite soils and limited areas of limestone soils provide sites for an abundance of other plants ranging from ferns and mosses, bamboos and rattans, to several hundred types of forest trees.

But there are several major development problems to be overcome to get optimum results: termination of all tin-mining licences; stabilisation of some ponds; construction of basic roads and trails; provision of a visitor information centre and/or nature museum. Templer Park is ideal for establishing a major nature centre to interpret the significance of park habitats as well as to stimulate interest in conservation.

\section{Batu Caves}

The most popular natural feature of the Kuala Lumpur area is the Batu Caves. Scenic, biologically significant, and a religious shrine for over 800,000 Tamil Hindus living in Malaya, it should be designated a national monument. Only in this way can it be protected and yet continue to be a superb recreational and educational resource for one of the densest populations in the Federation. Consisting of a high karst tower covering 400 acres - a fragment of the Permian-Carboniferous limestone mantle, over 100 metres thick, that once covered most of Malaya - with peaks rising to over 800 feet above the valley floor, the massif's exposed surface is covered with crevices and pits, while its interior contains many channels that reveal the erosive powers of ancient streams.

Two caverns are open to the public. The smaller one, the most frequently visited, includes a vaulted chamber with a huge collapsed room at one end that has been dedicated as the Hindu Sri Mariammar Temple since the last century. The much larger and longer Dark Cave extends over a half mile into the limestone and consists of several high-roofed chambers, one covering more than two acres. In addition, the cave has immense stalactites and stalagmites, cascades of black stone, and a blood-red wall caused by colonies of minute algae. Several of the chambers are dimly illuminated through small chimneys in the roof. As a habitat the cave is unique, with at least 167 species living in the relatively closed environment (McClure 1961, 1967). Since plant growth is limited by darkness, the only nutrient material is that brought into the caves daily by bats, and the whole food complex of parasites, predators, and scavengers is dependent directly or indirectly on the bats, their guano, and their corpses. Vertebrates in the cave include five bat species, four frogs and toads, and five snakes and lizards.

The many rare plants include Echinodorus ridleyi, first discovered in 1900 and regarded by botanists as a primitive survivor from the time of the division of flowering plants into Monocotyledons and Dicotyledons. 
A fine example of the tropical relict flora, it was able to survive because of the unique habitat the limestone offered. Unfortunately, relict species that managed to hang on for millions of years are now hastened to extinction by man's destruction of habitat.

Since the discovery of Batu Caves in 1879 damage has gradually increased. At first, the bat guano was extracted and used as fertiliser. Then, quarries began producing crushed rock for use as ballast, etc. Present users include a fertiliser plant requiring dolomite and a cement company quarrying for calcite. The process of blasting the limestone cliffs is continuing, and besides disfiguring the landscape, there is a serious threat that both the Dark and Temple Caves will be destroyed.

\section{Kuala Selangor}

Also within an hour's drive of Kuala Lumpur, Kuala Selangor offers great potential as the seventh core unit in the proposed national park system. About 1280 acres, it is one of Malaysia's historic places, with two forts as relics of a proud past. Biologically it consists of a granite hill partly surrounded by a tidal mangrove forest, which shelters several types of fauna not easily seen elsewhere.

The flora on the hill has largely been disturbed by constant habitation, but that of the mangrove belt is a fine sample of the forest extending for more than 500 square miles along the west coast. Mangrove typically is a tidal forest that colonises mudflats deposited by drainage from the interior. The pioneer species - Avicennia and Sonneratia sp - become established because of their specialised seed structures and growth habits, and their presence gradually modifies the environment until larger and more durable species -Rhizophora and Bruguiera sp - replace them. The successive bands of floral environments that are so characteristic of the mangrove forest phenomenon can clearly be seen at Kuala Selangor.

Mangrove provides a habitat for many interesting animals, including the relatively rare silvered-leaf monkey Presbytis cristatus. A troop of several dozen regularly wander through the swamp forest in Kuala Selangor and up into the rain trees Enterolobium samans on top of the hill, and a troop of long-tailed macaques regularly patrols the terrain between the hill and the mangrove - feeding on the crabs and other crustaceans in the tidal zone. Birdlife is abundant because many species from a variety of nearby habitats - sea, mangrove and the interior mingle together here. The brahminy kite Haliastur indus, the honey buzzard Pernis apivorus, the lesser adjutant stork Leptoptilos javanicus and house crows Corvus splendens are commonly seen and there are many reptiles and amphibians.

The national monument should be large enough to encompass the entire hill, both forts and some of the adjacent mangrove and mudflats. The hill fauna is partially protected within a legislated 108-acre game reserve, but to be totally effective the reserve should be enlarged to include the total daily range of the animals. The minimum size of the park should be two square miles. The optimum size would include many square miles of the adjacent Banjor Forest Reserve. It would also be wise to include the zone of tidal mudflats bordering the mangrove, for these are important feeding grounds for sea birds and waders. 


\section{REFERENCES}

ALLEN, Betty Molesworth, 1961 Limestone hills near Ipoh. Malayan Nature Journal, Special Issue. p 68-72.

DUNN, Frederick L. 1965 Gua Anak Takun, ecological observations. Malayan Nature Journal 19: 75-87.

HENDERSON M.R. 1939. Flora of the limestone hills of the Malay Peninsula. Journal of the Royal Asiatic Society.

McCLURE, H. Elliott. 1961. Batu Caves, Kuala Lumpur. Malayan Nature Journal, Special Issue. $p$ 73-78.

-, Boo Liat Lim and Sarah E. Winn. 1967 Fauna of the Dark Cave, Batu Caves, Kuala Lumpur, Malay sia. Pacific Insects 9(3): 339-428.

MERTON, Francis. 1962. A visit to Tasek Bera. Malayan Nature Journal 16: $103-110$.

MITCHELL, B.A. 1959. Ecology of tin mine spoil heaps. Malayan Forester 22(2): 111-132.

WEBER, Bruce E. 1968. A national park system for West Malaysia. Federal Game Department. 41pp.

In Oryx, January 1972, Dr Robert Bustard proposed that a national park be created at Trengganu, on Malay sia's west coast, to enclose the laying beaches of the leathery turtle. Mr Weber, and his colleague Dr W.E. Stevens, agree that the leathery turtle's situation calls for immediate conservation action but suggest the area should more appropriately be declared a 'wildlife sanctuary'.

\section{Mammals in Nigeria}

\section{David Happold}

In the article 'New Attitudes in Nigeria', by John Henshaw and Gilbert S. Child (Oryx 11, 4: 275-283) there are some errors which I should like to correct, although lack of information on the distribution of many species makes it difficult to be precise.

Duikers There is confusion between the nomenclature of Maxwell's duiker Cephalophus maxwelli, which occurs in the forest zone of Nigeria west of the Niger river and further west to Senegal, and the blue duiker $C$. monticola, which is supposed to occur east of the Niger river and eastwards into Cameroon and central Africa. If it is shown that maxwelli and monticola are synonomous, there will of course be just one species with a very wide distribution, but until this is resolved it is best to retain the two names. The black duiker $C$. niger was once fairly common in southern Nigeria west of the Niger river, but it is doubtful if it still exists. The yellow-backed duiker $C$. sylvicultor occurs on both sides of the Niger river but is now extremely rare.

Pigs. The red river hog or bush pig, Potamochoerus porcus, is found on both sides of the Niger river. It is not uncommon in the remote forest areas of western Nigeria, and its range extends northwards into the forest relics in the derived savanna.

Primates. The black colobus monkey Colobus polykomos was frequently seen many years ago, but I have not heard of any definite records for several years. As elsewhere in Africa, it has been shot for its skin, and in Nigeria most of the shooting has been done by local Africans with 'Dane' guns. 